\title{
Indication of Use Level Technical Component of Economic Activity in Processing Organizations
}

\author{
Khorev A.I.* \\ Voronezh State University of Engineering Technologies \\ Voronezh, Russia \\ e-mail: ebfm254@yandex.ru
}

\author{
Nuzhdin R.V. \\ Voronezh State University of Engineering Technologies \\ Voronezh, Russia \\ e-mail: rv.voronezh@gmail.com
}

\author{
Belyaeva G.V. \\ Voronezh State University of Engineering Technologies \\ Voronezh, Russia \\ e-mail: kafbuhuchet@yandex.ru
}

Ponomareva N.I.

Voronezh State University of Engineering Technologies

Voronezh, Russia

e-mail: ponomareva220387@yandex.ru

\author{
Pukhova M.M \\ Voronezh State University of Engineering Technologies \\ Voronezh, Russia \\ e-mail: pumochka19@mail.ru
}

\begin{abstract}
Digitalization of economy is associated with the acceleration of business processes, the adoption of effective management decisions, the development of which is based on information about the state and use of the main components of economic activity, including technical. Traditional approaches to the analysis of fixed assets include phased calculations of indicators that only fragmentary take into account the sequence of movement of the studied objects in the organization and, therefore, are of limited use. To eliminate existing methodological shortcomings, attributive-meaningful relationships between key static and dynamic indicators that take into account the specific features of sugar production and systematically cover the entire process of movement of the value of property, plant and equipment in the organization are identified and justified. A fivestage algorithm of business analytical procedures has also been developed, which allows identifying benchmarks for making proactive management decisions in terms of mobilizing the possibilities of intensive use of capital assets of processing organizations. Testing of the methodology for indicating the level of use of the technical component of economic activity was carried out based on the materials of seven sugar production organizations of the Voronezh region for the period 2014-2018; dynamic rating was carried out separately for each organization for each year, which allowed establishing the prevailing influence of factors of the external business environment on the results of using the technical component. The integrated rating of the organizations were carried out over each year and in general over a five-year period, which made it possible to ascertain the presence of unused and underused opportunities and the ambiguity of implemented management decisions aimed at developing the technical component; it is concluded that it is necessary to implement a systematic approach to indicating the level of use of the technical component of economic activity, ensuring a one-time assessment of the mobile elements of resource capital (material and labor) and the non-mobile element.
\end{abstract}

Keywords - sugar production; item of fixed assets; technical component; analytical procedures; key indicators.

\section{INTRODUCTION}

The search for opportunities for the competitive development of economic activities of organizations is generated in the areas of intensification of the use of raw materials, labor and technical components. As the distinguishing features of the latter we can identify:

- the high cost of measures to update fixed assets and the development of the technical component;

- a high degree of predictability of the results on the development of the technical component;

- a long period of use of fixed assets;

- various accounting methods for updating and developing the technical component $[3 ; 5 ; 13]$;

- significant impact of the level of development of the technical component on the raw material and labor components.

The listed features and specifics of sugar production, despite their significance, are fragmented or completely ignored even at the methodological level, which in some way complicates the process of identifying the unused opportunities of the resource potential and, as a result, the development of effective management decisions [6-8, 13]. Therefore, there is an inevitable need to adjust traditional analytical tools and update their information and methodological support.

The purpose of this work is to justify a system of key static and dynamic indicators for assessing the technical component of the economic activity of sugar production organizations; development of assessment procedures, providing the 
possibility of comparative object-by-object analysis of the technical component in space and time; characteristics of the analytical capabilities and information capacity of financial and statistical reporting.

\section{METHODS AND MATERIALS}

In contrast to traditional approaches under the technical component we mean the entire set of fixed assets related to the economic activity of the organization, and not just their main part, because, firstly, for use of machines, equipment and other active objects in the production, buildings and structures are needed, which, in turn, are located on land plots; secondly, considering the technical component of the resource potential and evaluating the resource return. It is necessary to take into account that organizations invest heavily in these objects.

It is necessary to note that in Russian analytical practice, most authors confine themselves to considering complexes of traditional indicators of return and movement of fixed assets that underestimate the system properties of their analytical suitability - namely, the classification features of static, dynamic, and also quantitative, and qualitative features $[1 ; 2 ; 4-8 ; 15]$.

It is especially necessary to emphasize that the indicators of return on fixed assets currently used in economic analysis to assess the degree of use of the technical component underestimate the processes of movement of their value [8-10; 16-17]:

- in most cases, the cost of fixed assets leased is not taken into account, despite their use, including in core activities;

- income does not include income derived from other types of activities (for example, from the rental of fixed assets, the provision of other services for their use or their sale), although during the analysis the fixed assets are not divided into any groups;

- the time factor of the use of fixed assets is not taken into account, which is especially important for sugar production, when part of the products is sold in the next reporting financial period, respectively, income from its sale is not included in the calculations of the reporting financial period.

To ensure the integrity and consistency of reasoning regarding the procedures of the methodological approach proposed for evaluating the labor and raw material components [11-12], as well as eliminating the noted shortcomings, the necessary and sufficient, in our opinion, are:

- selection of objects and periods of assessment;

- selection and justification of key static and dynamic indicators;

- selection of key indicators assessment methodology (rating).

The selection of objects of assessment should be based on the unity of the applied methods and approaches of accounting and, as a consequence, the comparability of the source data and the results of the analysis. This aspect is especially important when performing assessment procedures, since in different organizations the elements of accounting policies for accounting purposes of fixed assets can vary significantly, which can negatively affect the interpretation of the values of individual indicators.

The recommended assessment period is 5 years.

The formation of the system of key indicators was carried out by us taking into account:

- the unity of approaches to assessing and accounting for the presence and movement of fixed assets in different subjects of economic activity;

- system causal links of static and dynamic indicators corresponding to specific business processes.

Tables 1 and 2 show the main indicators traditionally used in conducting economic analysis of fixed assets. Static indicators are grouped by us in accordance with the classification of fixed assets used in the sugar factories under research. Land plots are classified as fixed assets whose consumer properties do not change over time and for which depreciation is not charged. In this regard, the expiration rate should be determined separately for each group of fixed assets, and when calculating this indicator for the organization as a whole, we propose not to take into account the cost of land, which will increase the analytical value of the results.

TABLE I. TRADITIONAL STATIC INDICATORS CHARACTERIZING THE CONDITION OF THE TECHNICAL COMPONENT

\begin{tabular}{|l|c|c|}
\hline \multicolumn{1}{|c|}{ Classification groups } & \multicolumn{2}{c|}{ Static indicators } \\
& Quantitative & \multicolumn{1}{c|}{ Qualitative } \\
\hline Land plots & Area, cost & \\
\hline Buildings & & \\
\cline { 1 - 1 } $\begin{array}{l}\text { Machines and equipment (except } \\
\text { office) }\end{array}$ & & \\
\hline Constructions & & \\
\hline Production and household equipment & & \\
\hline Office equipment & & $\begin{array}{l}\text { Expiration rate, } \\
\text { depreciation coefficient }\end{array}$ \\
\hline Other types of fixed assets & & \\
\hline Vehicles & &
\end{tabular}

In addition, it seems unnecessary to include in the system key indicators of polar coefficients (for example, expiration and wear), the simultaneous use of which does not provide a commensurate increase in the resulting content.

The capital-labor ratio, which characterizes the level of technical equipment of personnel with the active part of fixed assets, is perceived by us as a static indicator, since it is calculated on a specific date and its values can change even in the absence of results of movement, use or change of fixed assets, for example, in the case of dynamics of labor resources. At the same time, the traditional approach to calculating the indicator does not take into account the cost of leased fixed assets and does not provide an opportunity to assess the level of staffing with the immobilized component of the resource potential. Therefore, in the system of key indicators of the technical component (table 3), we propose to include precisely the indicator of capital-labor ratio, which is more correct from the point of view of professional terminology and has greater analytical suitability. 
TABLE II. TRADITIONAL DYNAMIC INDICATORS CHARACTERIZING PROCESSES OF MOVEMENT, USE AND CHANGE OF ELEMENTS OF TECHNICAL COMPONENT

\begin{tabular}{|l|l|l|l|}
\hline \multirow{2}{*}{ Processes } & \multicolumn{1}{|c|}{ Subprocesses } & \multicolumn{1}{c|}{ Quantitative } & \multicolumn{1}{c|}{ Qualitative } \\
\cline { 3 - 4 } & 1.1 Income & Initial cost increase & Update (income) rate \\
\cline { 2 - 4 } & 1.2 Outflow & $\begin{array}{l}\text { Decrease in initial, residual } \\
\text { cost }\end{array}$ & Retirement rate, liquidation rate \\
\hline \multirow{4}{*}{2.1 Production } & $\begin{array}{l}\text { Volume of production, } \\
\text { amount of accrued } \\
\text { depreciation }\end{array}$ & $\begin{array}{l}\text { Capital productivity, capital productivity of the active part } \\
\text { of fixed assets, capital intensity, return on assets, } \\
\text { utilization of production capacity rate }\end{array}$ \\
\cline { 2 - 4 } & 2.2 Rental & $\begin{array}{l}\text { Income from leased fixed } \\
\text { assets }\end{array}$ & Capital productivity of leased fixed assets \\
\hline \multirow{2}{*}{3.1 Reassessment } & $\begin{array}{l}\text { Change in replacement cost } \\
\text { Change in initial cost as a } \\
\text { result of modernization }\end{array}$ & Production capacity increase \\
\cline { 2 - 4 } & 3.2 Modernization & Maintenance costs & Hardware failure rate, whole day downtime \\
\cline { 2 - 4 } & 3.3 Maintenance &
\end{tabular}

The first block of the system of key indicators (table 3) static indicators, in addition to the expiration rate and capital ratio, includes the unit cost of production capacity, which allows evaluating the effectiveness of investments in the technical component from the standpoint of target formation and development of resource potential. The use of the initial cost of fixed assets in calculations in accordance with the developed methodology eliminates the need for adjustments taking into account the actual life, but requires comparability of the approaches used to reassessment of fixed assets.

Income and outflow ratios structurally characterize the change in the initial cost of fixed assets. Some authors advise analyzing their values simultaneously, that is, comparing with each other, which as a result will allow concluding either about the expanded reproduction of fixed assets, or about reverse processes. In our opinion, for the adoption of such a decision, the calculation of these indicators is optional. This is predetermined by the following assumptions: firstly, only the initial cost is used in the calculations, and secondly, the value at the end of the period is the difference between the amount of value at the beginning of the period and the value of the received fixed assets and the value of the retired objects. Thus, it is enough to compare the value of incoming and outgoing fixed assets - a large cost a priori will provide a higher level of the corresponding ratio. Moreover, if the organization does not increase production capacity, their level should vary in the range of comparable values. The assessment of these coefficients will be useful in calculating the estimated time period for updating a separate group of homogeneous fixed assets of the organization, for example, computers.

TABLE III. SYSTEM OF KEY INDICATORS FOR ASSESSING THE TECHNICAL COMPONENT OF ECONOMIC ACTIVITY OF SUGAR PRODUCTION

\begin{tabular}{|c|c|c|}
\hline Indicator & Calculation formula & $\begin{array}{l}\text { Content and essence } \\
\text { (analytical suitability) }\end{array}$ \\
\hline \multicolumn{3}{|c|}{ Static indicators } \\
\hline $\begin{array}{l}1 \text { Expiration rate, } \\
\left(\mathrm{R}_{\mathrm{e}}\right)\end{array}$ & $\begin{array}{l}\mathrm{R}_{\mathrm{e}}=\mathrm{RC} / \mathrm{IC} \text {, where } \\
\mathrm{RC}-\text { the average annual residual cost of fixed assets, thous rub } \\
\mathrm{IC}-\text { the average annual initial (replacement) cost of fixed } \\
\text { assets, thous rub }\end{array}$ & $\begin{array}{l}\text { It characterizes the possibility of exploitation of fixed assets in the } \\
\text { future; } \\
\text { shows what proportion of the initial cost of fixed assets is not } \\
\text { depreciated }\end{array}$ \\
\hline $\begin{array}{l}2 \text { Capital-labor ratio. } \\
\left(\mathrm{C}_{1}\right)\end{array}$ & $\begin{array}{l}\mathrm{C}_{\mathrm{l}}=\left(\mathrm{RC}+\mathrm{L}_{\mathrm{r}}\right) / \mathrm{N}^{*} 100, \text { where } \\
\mathrm{N}-\text { number of staff, pers. } \\
\mathrm{L}_{\mathrm{r}}-\text { the average annual value of leased fixed assets, thous rub }\end{array}$ & $\begin{array}{l}\text { It characterizes the level of equipment of the organization's personnel } \\
\text { with fixed assets; } \\
\text { shows how much the cost of fixed capital falls on one employee of the } \\
\text { organization }\end{array}$ \\
\hline $\begin{array}{l}3 \text { Unit cost of } \\
\text { production capacity, } \\
\text { rub / unit c }\left(\mathrm{U}_{\mathrm{c}}\right)\end{array}$ & $\begin{array}{l}\mathrm{Uc}=\mathrm{IC} / \mathrm{C}, \text { where } \\
\mathrm{C}-\text { production capacity (design), thousand tons/day. }\end{array}$ & $\begin{array}{l}\text { It characterizes the balance of the cost of fixed assets and production } \\
\text { capabilities of the organization; } \\
\text { shows how many fixed assets are per unit of production capacity of the } \\
\text { organization }\end{array}$ \\
\hline \multicolumn{3}{|c|}{ Dynamic indicators } \\
\hline $\begin{array}{l}4 \text { Production capital } \\
\text { return, } t / \text { ruble. }\left(R_{1}\right)\end{array}$ & $\begin{array}{l}\mathrm{R}_{1}=\mathrm{V}_{\text {prod }} /\left(\mathrm{RC}+\mathrm{L}_{\mathrm{r}}\right) \text {, where } \\
\mathrm{V}_{\text {proc }}-\text { the volume of processed beet raw materials, thous tons }\end{array}$ & $\begin{array}{l}\text { It characterizes the role of the technical component in the production of } \\
\text { the main and by-products; } \\
\text { shows how much processed sugar beets is per ruble cost of used fixed assets }\end{array}$ \\
\hline $\begin{array}{l}5 \text { Cost return on } \\
\text { capital, ruble/ruble } \\
\left(\mathrm{R}_{2}\right)\end{array}$ & $\begin{array}{l}\mathrm{R}_{1}=\mathrm{AV} /\left(\mathrm{RV_{ \textrm {a } }}+\mathrm{L}_{\mathrm{r}}\right) \text {, where } \\
\mathrm{AV} \text {-added value, thousand rub, } \\
\mathrm{RV} \mathrm{V}_{\mathrm{a}} \text { - the average annual residual value of the active part of } \\
\text { fixed assets, thous rub. }\end{array}$ & $\begin{array}{l}\text { It characterizes the role of the active part of the technical component in } \\
\text { the process of adding value; } \\
\text { shows how much value added is per ruble of the active part of own and } \\
\text { leased fixed assets }\end{array}$ \\
\hline $\begin{array}{l}6 \text { Cost of using fixed } \\
\text { assets, ruble/ruble } \\
\left(\mathrm{C}_{\mathrm{fa}}\right)\end{array}$ & $\begin{array}{l}\mathrm{C}_{\mathrm{fa}}=(\mathrm{D}+\mathrm{Cr}) /\left(\mathrm{RC}+\mathrm{L}_{\mathrm{r}}\right), \text { where } \\
\mathrm{D}-\text { depreciation of fixed assets, thousand rubles., } \\
\mathrm{C}_{\mathrm{r}}-\text { rental costs of fixed assets }\end{array}$ & $\begin{array}{l}\text { It characterizes the level of expenses of the organization for the use of } \\
\text { fixed assets; } \\
\text { shows how much depreciation and lease payments account for the ruble } \\
\text { of fixed assets }\end{array}$ \\
\hline $\begin{array}{l}7 \text { Resource } \\
\text { compliance rate, } \\
\text { ruble/ruble } \\
\left(\mathrm{R}_{\mathrm{r}}\right)\end{array}$ & $\begin{array}{l}\mathrm{R}_{\mathrm{r}}=(\mathrm{LC}+\mathrm{M} 3) /(\mathrm{RV}+\mathrm{Lr}), \text { where } \\
\mathrm{LC}-\text { labor costs, thous rub } \\
\mathrm{MC}-\text { material costs, thous rub }\end{array}$ & $\begin{array}{l}\text { It characterizes the relationship of raw materials, labor and technical } \\
\text { components of current activities; } \\
\text { shows how much expenditure on material resources and labor costs } \\
\text { account for the ruble of fixed assets }\end{array}$ \\
\hline
\end{tabular}


From a utilitarian point of view, the methodology for calculating the coefficient of updating intensity does not correspond to the semantic load, since the result of dividing the value of retired fixed assets by the value of received does not reflect the "intensity of updating" and practically does not characterize anything. In order to update all of the organization's fixed assets, multidirectional processes are simultaneously needed: income and disposal (it is impossible to update anything without income, but the mere disposal of facilities over time will definitely lead to production shutdown). If we assume that the same fixed assets are dropped out and arrive in the same period, that is, the old objects are replaced with new ones, then the ratio of their value in any variation will indicate how much new (old) objects are more expensive (cheaper) relative to old (new) objects. Given the growing pace of development of technology to meet competitive technologies, as well as inflationary processes, we can assume that the initial cost of the received fixed assets will in most cases be higher than the replacement cost of the retired facilities, even taking into account the results of the reassessment of the latter. Therefore, we did not include the considered coefficients in the system of key indicators.

In table 3 , the return on assets is presented by two indicators: in the first case, an assessment is given in kind (the volume of processed beet raw materials is used, which, unlike the volume of production, makes it possible to level the influence of the value factor of the raw material component); in the second case, the valuation is based not on the mass of income from ordinary activities, but on value added, the analytical advantages of which have been repeatedly substantiated in special theoretical and practical works [14-15; $18]$.

\section{RESULTS}

The identification of the best organizations by the level of technical component assessment, including comparative analysis tools, is advisable to be carried out on the basis of rating, which provides sufficient accuracy and reliability.

We recommend the following business analysis of the technical component, combining the advantages of a comparative and rating assessment ${ }^{1}$ :

values of key static indicators of the technical component of the economic activity of organizations are determined;

the values of key dynamic indicators of the technical component of the economic activity of organizations are determined;

all key indicators for each organization for a five-year period are ranked by the "sum of places" method according to the principle "dynamic rating of the year - place";

the integrated rating of the technical component of the economic activity of sugar factories on average over a fiveyear period on the principle of "best rating $=$ min sum of places" is determined by the method of "sum of places".
To test the developed methodology, we selected 7 sugar factories in the Voronezh region.

Stage 1. In order to obtain assessment results with high analytical potential, to exclude robust values and to provide the possibility of comparing organizations in space and time, we took into account specific production features inherent in this type of economic activity. The positive features of the economic activity of the surveyed sugar production organizations of the Voronezh region include the ongoing modernization and updating of fixed assets, which in some cases affects the growth of their expiration rate. The most significant measures for the development of the technical component in these organizations in recent years were:

- O1 - automation of filtration and saturation processes; increased fan performance for sugar drying; pulp press recovery; reconstruction of cooling towers, as well as installation of ventilation devices for blades (beet storage)

- $\mathrm{O} 2$ - overhaul of the evaporator, generators, diffusion apparatus;

- O3 - modernization: conveyor-wash water suspension pipeline to the filtration fields, evaporator, process control system of the pulp dryer; creation of a drainage system of the land plot (next to the desugarization workshop);

- O6 - the construction of a site for storing sugar beets; replacement of individual sections of the pipeline with filtration fields; embankment of filtration fields.

The calculated values of the static key indicators are given in table 4. A significant range of variations for all indicators, both for organizations for one year and for a group of organizations for the analyzed five-year period should be noted. At the same time, the largest dynamic deviations in organizations were identified by indicator 2 - capital-labor ratio, which is due to the ratio of the mobile (labor) and immobilized (technical) components of economic activity, the isolated vectors of which do not coincide precisely because of their varied nature.

The level of obtained values of the expiration rate in organizations $\mathrm{O} 5$ and $\mathrm{O} 2$ should be recognized, of course, low (less than 0.5 units). Since throughout the entire five-year period, annual investments in fixed assets of these organizations were insignificant; in 2019, O5 was liquidated. While maintaining the negative dynamics of the expiration rate and taking into account its actual level, the adoption of a similar decision in a few years is also possible for the organization of $\mathrm{O} 2$.

Stage 2. All dynamic indicators included in the system of key indicators can conditionally be considered one-class, since the average annual residual value of own and leased fixed assets is used as the basic element of the assessment procedures. The calculated values of the key dynamic indicators for the group of surveyed organizations are presented in table 5 .

${ }^{1}$ The procedure is developed by Nuzhdin RV 
TABLE IV. KEY STATIC INDICATORS OF TECHNICAL COMPONENT OF ECONOMIC ACTIVITY OF ORGANIZATIONS OF SUGAR PRODUCTION O1 - O7

\begin{tabular}{|c|c|c|c|c|}
\hline \multirow{2}{*}{$\begin{array}{c}\text { Organiza } \\
\text { tion } \\
\text { Code }\end{array}$} & \multirow{2}{*}{ Year } & \multicolumn{3}{|c|}{ Static indicators } \\
\hline & & $\begin{array}{c}\text { Expiration rate, } \\
\text { un. }\end{array}$ & $\begin{array}{c}\text { Capital-labor } \\
\text { ratio, ruble/pers. }\end{array}$ & \begin{tabular}{|l|} 
Unit cost of production \\
capacity, ruble./ un.c /
\end{tabular} \\
\hline & 2014 & 0.60 & 2010 & 184 \\
\hline & 2015 & 0.62 & 2198 & 216 \\
\hline & 2016 & 0.59 & 2317 & 241 \\
\hline & 2017 & 0.54 & 2312 & 282 \\
\hline & 2018 & 0.52 & 2219 & 321 \\
\hline & 2014 & 0.52 & 1030 & 191 \\
\hline & 2015 & 0.46 & 907 & 192 \\
\hline & 2016 & 0.41 & 749 & 192 \\
\hline & 2017 & 0.36 & 684 & 193 \\
\hline & 2018 & 0.32 & 659 & 192 \\
\hline & 2014 & 0.77 & 3198 & 256 \\
\hline & 2015 & 0.72 & 3466 & 315 \\
\hline & 2016 & 0.57 & 2669 & 395 \\
\hline & 2017 & 0.51 & 2223 & 359 \\
\hline & 2018 & 0.49 & 2490 & 383 \\
\hline & 2014 & 0.71 & 1179 & 129 \\
\hline & 2015 & 0.70 & 1234 & 137 \\
\hline & 2016 & 0.90 & 2617 & 230 \\
\hline & 2017 & 0.89 & 5151 & 294 \\
\hline & 2018 & 0.81 & 5960 & 395 \\
\hline & 2014 & 0.29 & 120 & 40 \\
\hline & 2015 & 0.24 & 92 & 40 \\
\hline & 2016 & 0.22 & 84 & 42 \\
\hline & 2017 & 0.22 & 89 & 43 \\
\hline & 2018 & 0.20 & 79 & 41 \\
\hline & 2014 & 0.40 & 351 & 67 \\
\hline & 2015 & 0.41 & 393 & 69 \\
\hline & 2016 & 0.53 & 509 & 73 \\
\hline & 2017 & 0.70 & 1150 & 128 \\
\hline & 2018 & 0.70 & 1639 & 181 \\
\hline & 2014 & 0.78 & 553 & 63 \\
\hline & 2015 & 0.72 & 500 & 64 \\
\hline & 2016 & 0.67 & 504 & 67 \\
\hline & 2017 & 0.62 & 502 & 71 \\
\hline & 2018 & 0.63 & 641 & 84 \\
\hline
\end{tabular}

A very significant range of variations in the values of dynamic key indicators is due to the following circumstances:

characteristics of the technical component (production capacity, cost of fixed assets, degree of deterioration, ratio of active and inactive parts of fixed assets);

managerial decisions (strategic managerial, involving the development of directions for the development of organizations, and tactical production, providing only the maintenance of their performance)

The values of capital return of production very significantly vary in the range from $0.3 \mathrm{t} / \mathrm{rub}$ up to $11.32 \mathrm{t} / \mathrm{rub}$., cost return - from 0.42 to $22.26 \mathrm{rub} / \mathrm{rub}$, the value of the cost of using fixed assets - from $0.07 \mathrm{rub} / \mathrm{rub}$ up to $0.87 \mathrm{rub} / \mathrm{rub}$, the level of the resource compliance rate - from 0.48 to $38.90 \mathrm{rub} / \mathrm{rub}$. A significant range of variations in the values of key indicators for organizations is due to factors of a physical and monetary nature, namely, varying degrees of functional depreciation of fixed assets and a significant share of leased fixed assets in individual organizations.

The best results in most cases were achieved in organizations $\mathrm{O} 1$ and $\mathrm{O} 3$, insufficiently effective in organizations $\mathrm{O} 4$. The remaining organizations with the same key indicators in different periods showed a multilevel value, that is, the sustainability of economic activity was not observed.

TABLE V. KEY DYNAMIC INDICATORS OF TECHNICAL COMPONENT OF ECONOMIC ACTIVITY OF ORGANIZATIONS OF SUGAR PRODUCTION O1 - O7 OF THE VORONEZH REGION (2014-2018)

\begin{tabular}{|c|c|c|c|c|c|}
\hline \multirow[b]{2}{*}{$\begin{array}{c}\text { Organiz } \\
\text { ation } \\
\text { Code }\end{array}$} & \multirow[b]{2}{*}{ Year } & \multicolumn{4}{|c|}{ Dynamic indicators } \\
\hline & & $\begin{array}{c}\text { Production } \\
\text { capital return, } \\
\text { t/rub }\end{array}$ & \begin{tabular}{|c} 
Cost \\
return on \\
capital, \\
rub/rub
\end{tabular} & $\begin{array}{c}\text { Cost of using } \\
\text { fixed assets, } \\
\text { rub/rub }\end{array}$ & $\begin{array}{c}\text { Resource } \\
\text { compliance rate, } \\
\text { rub/rub }\end{array}$ \\
\hline & 2014 & 0.30 & 0.45 & 0.15 & 0.90 \\
\hline & 2015 & 0.45 & 1.35 & 0.16 & 1.74 \\
\hline & 2016 & 0.57 & 1.51 & 0.17 & 1.95 \\
\hline & 2017 & 0.59 & 0.98 & 0.12 & 1.50 \\
\hline & 2018 & 0.62 & 1.42 & 0.18 & 2.37 \\
\hline & 2014 & 0.75 & 1.02 & 0.14 & 0.87 \\
\hline & 2015 & 0.98 & 3.30 & 0.16 & 2.33 \\
\hline & 2016 & 1.52 & 3.84 & 0.17 & 3.81 \\
\hline & 2017 & 1.94 & 1.99 & 0.19 & 4.50 \\
\hline & 2018 & 1.41 & 3.38 & 0.87 & 4.51 \\
\hline & 2014 & 0.45 & 1.04 & 0.28 & 1.14 \\
\hline & 2015 & 0.38 & 1.80 & 0.38 & 1.77 \\
\hline & 2016 & 0.74 & 2.83 & 0.46 & 2.87 \\
\hline & 2017 & 0.71 & 2.04 & 0.32 & 2.82 \\
\hline & 2018 & 0.62 & 2.16 & 0.14 & 2.98 \\
\hline & 2014 & 0.84 & 1.27 & 0.14 & 1.78 \\
\hline & 2015 & 0.85 & 3.65 & 0.16 & 2.78 \\
\hline & 2016 & 0.50 & 1.32 & 0.09 & 1.39 \\
\hline & 2017 & 0.37 & 0.42 & 0.12 & 1.00 \\
\hline & 2018 & 0.34 & 0.45 & 0.14 & 0.48 \\
\hline & 2014 & 4.56 & 8.39 & 0.33 & 10.01 \\
\hline & 2015 & 7.97 & 14.36 & 0.31 & 30.68 \\
\hline & 2016 & 11.03 & 22.26 & 0.46 & 38.90 \\
\hline & 2017 & 11.32 & 9.31 & 0.47 & 28.84 \\
\hline & 2018 & 8.68 & 13.10 & 0.57 & 31.60 \\
\hline & 2014 & 1.22 & 1.41 & 0.07 & 3.08 \\
\hline & 2015 & 2.14 & 4.98 & 0.09 & 4.87 \\
\hline & 2016 & 2.84 & 7.76 & 0.10 & 7.39 \\
\hline & 2017 & 1.49 & 1.84 & 0.08 & 4.29 \\
\hline & 2018 & 1.15 & 1.72 & 0.12 & 2.55 \\
\hline & 2014 & 1.64 & 6.98 & 0.20 & 3.71 \\
\hline & 2015 & 2.13 & 16.11 & 0.19 & 7.91 \\
\hline & 2016 & 2.38 & 18.87 & 0.23 & 7.68 \\
\hline & 2017 & 2.58 & 10.56 & 0.25 & 6.25 \\
\hline & 2018 & 1.61 & 6.62 & 0.16 & 3.97 \\
\hline
\end{tabular}

Stage 3. At this stage, the analytical tool "sum of places" ranged the key indicators for each organization for each year, while the best value of the indicator was assigned "1st place", the worst - "7th place". When assessing the indicators "unit cost of production capacity" and "cost of using fixed assets", the lowest value was recognized as the best; for the remaining indicators, the opposite criterion was used.

Stage 4 . The integrated ratings that we determined at this stage through the ranking of organizations were defined as the weighted average number of "sum of places" as a whole for the analyzed period for all key indicators. The calculation results are shown in table 6.

Integral rating made it possible to divide the organizations under study into two groups: the first - leaders (sum of places 
for a period of no more than 125) - $07,06,05$; the second is outsiders (the sum of places for a period of more than 125) $\mathrm{O} 4, \mathrm{O} 2, \mathrm{O} 3, \mathrm{O} 1$. The obtained results clearly confirm the validity of the results of the assessment of the technical component of the economic activity of processing organizations, ranked by the deviations of their key indicators and their place in the integrated rating. The following circumstances are meant:

- the key indicators of leading organizations generally have larger differences in deviations from the average integrated results than outsiders, that is, these organizations have more unused and underused opportunities;

- the processes of updating fixed assets in most organizations are not intensive enough, which also indicates a certain lack of demand for the idea of recognizing the equal effectiveness of the mobile and non-mobile components of economic activity.

\section{CONCLUSION}

In most cases, the management of processing organizations does not pay enough attention to assessing the technical component of economic activity; priority is given to the mobile component of resource capital. Such a fragmented approach and the use of traditional analytical tools do not allow full identification the unused and underused opportunities of the competitive solvency of organizations. It is advisable to evaluate the effectiveness of the technical component of economic activity on the basis of the developed system of key static and dynamic indicators that substantively complement and improve traditional methods. It is advisable to identify the best organizations by the level of technical component assessment, including for benchmarking, using rating tools that provide sufficient accuracy and reliability.

The performed procedures for indicating the level of the technical component of the economic activity of sugar production organizations of the Voronezh region for 20142018 revealed:

- a significant range of variations in the level of key indicators, which characterizes the ongoing measures to develop the technical component in most cases as successful;

- non-optimal level of correlation of individual key indicators (production and cost return), which indicates certain unused opportunities to enhance the use of fixed assets;

- the smallest level of deviations of the sum of the number of years from the average in organizations with higher daily sugar beet processing productivity ( $\mathrm{O} 1$ and $\mathrm{O} 3$ ), which allowed recognizing the prevailing influence of the factor "scale of production" on the state of their technical component as positive.

- The system of proposed key indicators will make it possible to assess the level of use of the technical component of the economic activity of processing organizations, to compare the results of the assessment not only for organizations in a particular region, but also for the whole country. In addition, the developed methodological approach can also be applied by processing organizations of other types of economic activity with a pronounced seasonality of production.

TABLE VI. INTEGRATED RATING ASSESSMENT OF KEY INDICATORS OF TECHNICAL COMPONENT OF ECONOMIC ACTIVITY OF ORGANIZATIONS OF SUGAR PRODUCTION O1 - O7 OF VORONEZH REGION (2014-2018), PLACE

\begin{tabular}{|c|c|c|c|c|c|c|c|c|}
\hline \multirow[t]{2}{*}{ Indicator } & \multirow[t]{2}{*}{ Year } & \multicolumn{7}{|c|}{ Organization Code } \\
\hline & & 01 & 02 & 03 & 04 & $O 5$ & 06 & 07 \\
\hline & 2014 & 4 & 5 & 2 & 3 & 7 & 6 & 1 \\
\hline & 2015 & 4 & 5 & 1 & 3 & 7 & 6 & 1 \\
\hline & 2016 & 3 & 6 & 4 & 1 & 7 & 5 & 2 \\
\hline & 2017 & 4 & 6 & 5 & 1 & 7 & 2 & 3 \\
\hline & 2018 & 4 & 6 & 5 & 1 & 7 & 2 & 3 \\
\hline & 2014 & 2 & 4 & 1 & 3 & 7 & 6 & 5 \\
\hline & 2015 & 2 & 4 & 1 & 3 & 7 & 6 & 5 \\
\hline & 2016 & 3 & 4 & 1 & 2 & 7 & 5 & 6 \\
\hline & 2017 & 2 & 5 & 3 & 1 & 7 & 4 & 6 \\
\hline & 2018 & 3 & 5 & 2 & 1 & 7 & 4 & 6 \\
\hline & 2014 & 5 & 6 & 7 & 4 & 1 & 3 & 2 \\
\hline & 2015 & 6 & 5 & 7 & 4 & 1 & 3 & 2 \\
\hline & 2016 & 6 & 4 & 7 & 5 & 1 & 3 & 2 \\
\hline & 2017 & 5 & 4 & 7 & 6 & 1 & 3 & 2 \\
\hline & 2018 & 5 & 4 & 6 & 7 & 1 & 3 & 2 \\
\hline & 2014 & 7 & 5 & 6 & 4 & 1 & 3 & 2 \\
\hline & 2015 & 6 & 4 & 7 & 5 & 1 & 2 & 3 \\
\hline & 2016 & 6 & 4 & 5 & 7 & 1 & 2 & 3 \\
\hline & 2017 & 6 & 3 & 5 & 7 & 1 & 4 & 2 \\
\hline & 2018 & 5 & 3 & 5 & 7 & 1 & 4 & 2 \\
\hline & 2014 & 7 & 6 & 5 & 4 & 1 & 3 & 2 \\
\hline & 2015 & 7 & 5 & 6 & 4 & 2 & 3 & 1 \\
\hline & 2016 & 6 & 4 & 5 & 7 & 1 & 3 & 2 \\
\hline & 2017 & 6 & 4 & 3 & 7 & 2 & 5 & 1 \\
\hline & 2018 & 6 & 3 & 4 & 7 & 1 & 5 & 2 \\
\hline & 2014 & 4 & 2 & 6 & 2 & 7 & 1 & 5 \\
\hline & 2015 & 2 & 2 & 7 & 2 & 6 & 1 & 5 \\
\hline & 2016 & 3 & 3 & 6 & 1 & 6 & 2 & 5 \\
\hline & 2017 & 2 & 4 & 6 & 2 & 7 & 1 & 5 \\
\hline & 2018 & 5 & 7 & 2 & 2 & 6 & 1 & 4 \\
\hline & 2014 & 6 & 7 & 5 & 4 & 1 & 3 & 2 \\
\hline & 2015 & 7 & 5 & 6 & 4 & 1 & 3 & 2 \\
\hline & 2016 & 6 & 4 & 5 & 7 & 1 & 3 & 2 \\
\hline & 2017 & 6 & 3 & 5 & 7 & 1 & 4 & 2 \\
\hline & 2018 & 6 & 2 & 4 & 7 & 1 & 5 & 3 \\
\hline & 2014 & 35 & 35 & 32 & 24 & 25 & 25 & 19 \\
\hline & 2015 & 34 & 30 & 35 & 25 & 25 & 24 & 19 \\
\hline & 2016 & 33 & 29 & 33 & 30 & 24 & 23 & 22 \\
\hline & 2017 & 31 & 29 & 34 & 31 & 26 & 23 & 21 \\
\hline & 2018 & 34 & 30 & 28 & 32 & 24 & 24 & 22 \\
\hline & 2014 & 6 & 6 & 5 & 2 & 3 & 3 & 1 \\
\hline & 2015 & 6 & 5 & 7 & 3 & 3 & 2 & 1 \\
\hline & 2016 & 6 & 4 & 6 & 5 & 3 & 2 & 1 \\
\hline & 2017 & 5 & 4 & 7 & 5 & 3 & 2 & 1 \\
\hline & 2018 & 7 & 5 & 4 & 6 & 2 & 2 & 1 \\
\hline $\begin{array}{l}\text { Integrated sum } o \\
\text { general for the } p \\
\text { key indicators }\end{array}$ & or in & 167 & 153 & 162 & 142 & 124 & 119 & 103 \\
\hline $\begin{array}{l}\text { Integrated avera } \\
\text { the period }\end{array}$ & $\mathrm{g}$ for & 7 & 5 & 6 & 4 & 3 & 2 & 1 \\
\hline
\end{tabular}

\section{References}

[1] I. Abdukarimov, I. Narizhny, "Monitoring and analysis of fixed assets based on accounting (financial) statements", Socio-econ. phenomena and processes, vol. 6, no. 052, pp. 26-39, 2013. 
[2] E. Astrakhantseva, "Features of accounting and analytical support of fixed assets in the financial recovery procedure", Current issues of econ. and law, vol. 2, pp. 144-148, 2011.

[3] K. Vasilyeva, "Assessment characteristic of fixed assets in a competitive environment”, Modern Econ.: Probl. and Solut., vol. 3, no. 87, pp. 169-181, 2017.

[4] S. Volgin, "The use of capital productivity in the analysis of fixed assets of a commercial organization", Enterprise Manag., vol. 8, no. 2, pp. 71-75, 2008.

[5] P. Danilova, "Improving the accounting of fixed assets and analysis of the effectiveness of their use", Manag. Account., vol. 6, pp. 51-60, 2016.

[6] T. Zhurkina, T. Sabetova, "Improving the methods of analysis of fixed assets of the enterprise", Proc. of VSUET, vol. 1, pp. 273-282, 2018.

[7] S. Larina, Yu. Karpenko, E. Chicherova, "Feature analysis of fixed assets of the organization”, Univer. Bull., vol. 11, pp. 134-140, 2016.

[8] K. Larina, A. Karpunin, "Comparative characteristics of individual methodological approaches to the analysis of fixed assets and the effectiveness of their use", Int. J. of Hum. and Natural Sci., vol. 1, pp. 86-90, 2017.

[9] N. Moroz, T. Chernenko, "Analysis of the effectiveness and rational use of fixed assets”, Sci. J. KubSAU, vol. 128, no. 04, pp. 1274-1285, 2017.

[10] N. Muraveva, N. Talalaeva, "The assessment of target value of performance indicators of small and medium-sized companies' financial management with industry and regional environmental features", Proc. of the Voronezh State Univer. of Engineer. Technol., vol. 81, no. 2, pp. 290-300, 2019.
[11] R. Nuzhdin, E. Endovitskaya, "Assessment of the raw materials and labor components of sugar beet production: methodological justification", Sugar, vol. 11, pp. 50-54, 2018.

[12] R. Nuzhdin, E. Endovitskaya, "Assessment of the raw materials and labor components of sugar beet production: practical implementation", Part 2, Sugar, vol. 2, pp. 56-62, 2019.

[13] T. Serebryakova, "About some difficult issues of accounting and tax accounting of operations with fixed assets", Int. Account., vol. 22, iss.10, pp. 1111-1123, 2019.

[14] L. Sovik, Zh. Shumak, "A comparative approach to the study of factors influencing the use of material resources by enterprises of the meat processing industry", Econ. and Banks, vol. 2, pp. 37-42, 2015.

[15] D. Shageev, T. Chuhonceva, "Universal rapid method of assessment and management decision-making of situational problems in the enterprise", Proc. of the Voronezh State Univer. of Engineer. Technol., vol. 81, no. 2, pp. 359-376, 2019.

[16] S. Hughes, S. Lowensohn, E. Tefre, "Portable Power: An Application of IAS 16 Including Self-constructed Assets and the Revaluation Model”, Issues in Account. Ed., vol. 34, no. 2, pp. 61-71, May 2019.

[17] T. Sellhorn, C. Stier, "Fair value measurement for long-lived operating assets: Research evidence", Europ. Account. Rev., vol. 28, pp. 573-603, 2019.

[18] O. Toluwa, O. Power, "Fair Value Accounting: A Conceptual Approach", Int. J. Of Acad. Res. In Busin. And Soc. Sci., vol. 9 , pp. 683-696, 2019. 